\title{
DIFFERENCES OF SCIENCE PROCESS SKILLS PRE-SERVICE TEACHER ON PHYSICS EDUCATION AND BIOLOGY EDUCATION \\ Maison ${ }^{1}$, Retni Sulistioning Budiarti ${ }^{2 *}$, Sofia Christine Samosir ${ }^{3}$, Neng Ria Nasih ${ }^{4}$
}

${ }^{1,3,4}$ Physics Education, Faculty of Teaching and Education, Universitas Jambi, Indonesia, ${ }^{2}$ Biology Education, Faculty of Teaching and Education, Universitas Jambi, Indonesia.

Email: *retni.sulistiyoning@unja.ac.id

\section{Article History: Received on $20^{\text {th }}$ November 2019, Revised on $28^{\text {th }}$ March 2020, Published on $12^{\text {th }}$ April 2020}

\begin{abstract}
Purpose of the study: This study aims to determine the differences in the mastery of science process skills in experiment group students and control group students in basic physics practicum I in equilibrium material in physics education and biology education study programs. And to find out the description of the mastery of science process skills in the experiment and control group students in biology and physics education study programs.

Methodology: This research is a quantitative research type quasy experiment with a static group comparison design. To determine the experiment class and the control class, both classes will be given a pre-test first. In the comparison group, researchers did not randomly select two groups to be given treatment with a posttest without a pre-test. The results of the mastery of students' science process skills will be analyzed by descriptive statistics and inferential statistics.

Main Findings: The results of this study show that there are differences in the mastery of science process skills between students using Science Process Skills-based practicum guide books inquiry models with students who use conventional practicum guidebooks in each study program. Based on statistical parameters, SPS mastery in the experiment class is better than in the control class.

Applications of this study: This research can be used as input for the Physics Education Study Program at the Universitas Jambi to consider the use of SPS-based practicum guides.

Novelty/Originality of this study: The novelty of this study aims to know the description and assessment of the mastery of SPS in the experiment group students and the control group students in the basic physics practicum in equilibrium material in biology education and physics education study programs in the use of science process skills-based practicum guides with inquiry models.
\end{abstract}

Keywords: Difference, SPS (Science Process Skills), Practicum, Basic Physics, Equilibrium.

\section{INTRODUCTION}

Physics is considered difficult by students because students are not interested in learning physics (Astalini, Kurniawan, Perdana, \&Kurniasari, 2018). Learning physics has a good influence on life because the discovery of physics provides many advantages and good effects (Astalini, Kurniawan, Darmaji, Sholihah, \& Perdana, 2019). Students 'interests and abilities are needed to support students' attitudes towards learning physics (Astalini, Kurniawan, Melsayanti, \& Destianti, 2018). One way that can attract students' interest in learning physics is when doing practicum activities because students can do theories that are learned in real life. One of the learning in physics is learning through the practicum. Practicum is important learning from science education to achieve various cognitive, practical, and effective goals, for example, to understand science and how science works, by being involved in conducting science reviews, they can also help vulnerable things influence misunderstandings (Darmaji, et al, 2019), (Astalini, Darmaji, Kurniawan, Anwar, \& Kurniawan, 2019). Practicum aims to provide opportunities for students to find concepts that they want to know or prove concepts that they have learned previously when teaching face to face. In addition, this practicum also aims to develop student SPS. The success of practicum in developing students' knowledge and skills is influenced by the type of practicum guidelines used.

Practicum guides must be able to develop scientific learning skills and student process skills (Arifin, Silaban, \& Tarigan, 2017). In accordance with the statement of Misbah, Wati, Rif'at, \& Dyah (2018) the practicum will run well and smoothly if it is equipped with an appropriate practical guidebook. Students with a good attitude towards learning physics will have good cognitive abilities (Astalini, Kurniawan, Darmaji, Putri, \& Nawaningsih, 2019). One of the competencies that must be possessed by a teacher is pedagogic competence, namely the ability to educate and design learning that is interesting for students (Asrial, et al, 2019). Good competence must be possessed by a teacher in order to be able to provide good learning (Syarial, Asrial, Kurniawan \& Subandiyo, 2019). Students in the faculty of education are prospective professional educators who have the task of guiding, training and building one's knowledge (Asrial, Syahrial, Kurniawan, Subandiyo, \& Amalina, 2019). Advances in technology have influenced students in their learning process (Syahrial, et al, 2019). As a prospective physics teacher not only demands mastering physics but also must master SPS. With the ability of SPS teachers, they can conduct learning activities that increase student SPS (Agustina \& Saputra, 2016). One of the learning activities that can improve student SPS is through students' habits with scientific work. Good mastery of SPS will have implications in improving students' cognitive abilities (Darmaji, Kurniawan, \& Suryani, 2018). SPS can be used in observing, measuring, and planning hypotheses. 
Science process skills are thinking skills that are used to create knowledge, solve problems and formulate results (Karadan \& Hameed, 2016), (Kusuma, Rosidin, Abdurrahman, \& Suyatna, 2017). Students 'thinking abilities can also improve students' process skills (Ernawati, Damris, Asrial, \& Muhaimin, 2019). Science process skills consist of basic skills and integrated skills. Basic SPS are skills that are used to develop integrated SPS (Hirca, 2013). So students who master basic science process skills will be able to easily understand integrated SPS. Basic SPS are: observation, communication, classification, measuring, inferring and prediction and KPS integration include Identifying Variables, Create A Table Data, Making A Graph, Relationship Between Variables, Obtain and Process Data, Analyze Investigation, Arrange Hypotheses, determining operational variables, Designing Investigation, and Conducting Experiments (Rezba, Sprague, McDonnough, \& Matkins, 2007). Science process skills are the ability to process scientific thought and the ability to process actions to develop an understanding of scientific concepts through experiment activities (Darmaji, Kurniawan, Parasdila, \& Irdianti 2018).

To support students 'science process skills through practicum activities, they must have practicum guides that are able to improve students' science process skills. The process skill aspect is really needed in every step of practicum activities that should be contained in the practicum guide (Darmaji, Astalini, Rahayu, \& Maison, 2018). Conventional guidelines or guides that have not required students to find problems and solve independently, still cannot improve student SPS. So that SPS-based guideline is needed so that they can improve SPS students as professional teacher candidates. Science process skills are skills that must be possessed by physics education students as prospective teachers because science process skills involve physical and mental activities to acquire and master science process skills (Darmaji, et al, 2019). To find out the effectiveness of practicum guides that has been developed by Wijayanto (2018). The trial of using a large scale product aims to find out whether or not there are differences in SPS mastery between students who use SPS-based practical handbooks using inquiry models (after they have been developed) and students who use conventional handbooks (before they are developed). This study aims:

1. To determine the differences in the mastery of SPS in experiment group students and control group students in basic physics practicum I in equilibrium material in biology and physics education study programs.

2. To know the description of mastery of SPS in the students of the experiment group and control in the biology and physics education study program.

The hypothesis of this study is that there are differences in the mastery of students' science process skills in the experiment group and the control group in Biology Education and Physics Education.

\section{METHODOLOGY}

This research is an experiment type research with a statistical group research design. In the comparison group, the researcher will not randomly choose two groups to be given training. With posttest without pre-test (Gall, Gall, \& Borg, 2003).

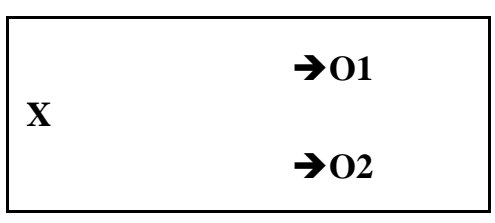

Figure 1: Statistical design of group comparison

Information: $\mathrm{X}=$ Treatment

$\mathrm{O} 1=$ Observation of the experiment group

$\mathrm{O} 2$ = Observation of the control group

The sampling technique used in this study is the total sampling technique. The total sampling technique is a technique that allows researchers to take samples from the entire population (Cohen, 2007). The sample in this study were semester 1 biology and physics education students consisting of 108 physics education students and 94 Biology Education students. The sample in this study was divided into two groups for the study program of Biology Education and physics education, namely the experiment group and the control group. The experiment and control groups were determined by giving a pre-test in the form of multiple-choice questions generally for all study samples. The instrument has alpha Cronbach 0.924 . Pre-test data were then analyzed using normality tests and homogeneity tests. If the results of the analysis show sig $=0.200$ at a significance level of $5 \%$, then the data is said to be normal, and if the results of the analysis show sig $=0.948$ at a significance level of $5 \%$, then the data is homogeneous. These results indicate that the cognitive abilities of students in the experiment group and the control group are the same so that there are no significant differences before being treated. After the experiment and control group are determined then a guide is given to each group. The experiment group is given SPS-based guidance and the control group is given a conventional guide. 
Data collection used by researchers by using observation and documentation. The observation was carried out to observe when students practiced. Observations were made by as many as 20 observers using the observation sheet. The observation sheet and the rubric observation sheet used are the adoptions of research conducted by Wijayanto (2018). To maintain the accuracy of the observational data, the observer used was given a previous explanation about the SPS. In addition, observers are also given directions on how to fill in the observation sheet based on the observation sheet rubric. The documentation study was carried out to complete the SPS observation data. With documentation studies, the results of observations will be more trusted. Then the observational data will be analyzed with descriptive and inferential statistics. Using the SPSS 24 software. Statistical parameters used include Mean, Median, Mode, Standard deviation, range, Maximum, Minimum, and Quartile. For mastery of each SPS, the indicator will be presented in the frequency distribution table and graph. SPS mastery in each indicator is divided into four categories, namely; Very Good, Good, Not Good and Very Not Good. The SPS mastery category for each indicator is presented in the following table.

Table 1: Interval mastery score the student science process skills (SPS)

\begin{tabular}{lcl}
\hline No. & Interval & Category \\
\hline 1 & $1.00-1.75$ & Poor \\
\hline 2 & $1.76-2.50$ & Low \\
\hline 3 & $2.51-3.25$ & High \\
\hline 4 & $3.26-4.00$ & Excellent \\
\hline
\end{tabular}

\section{DISCUSSION}

Science process skills are the ability of students to apply scientific methods to understand and discover new knowledge through practical activities.SPS is needed to demonstrate how to get scientific concepts. Practicum is learning that proves the principles and concepts of physics through experiment activities in the laboratory (Darmaji, Kurniawan, \& Irdianti, 2019). The novelty of this research is aimed at looking at the description and comparison of SPS mastery in experiment group students and control group students in basic physics practicum I of equilibrium material in biology and Physics Education study programs. The normality test data from the Physics Education student pre-test can be found in table 2 .

Table 2: Results of normality tests in Physics Education study programs

\begin{tabular}{cccc}
\hline & \multicolumn{3}{c}{ Kolmogorov-Smirnov } \\
\cline { 2 - 4 } & Statistik & Df & Sig. \\
\hline Experiment & 0.096 & 41 & $.200^{*}$ \\
\hline Control & 0.078 & 41 & $.200^{*}$ \\
\hline
\end{tabular}

The normality test was carried out at a significance level of 5\%, obtained significance values from the experiment group and the control group 0,200. Based on the significant value it can be concluded that the mastery of SPS data in the experiment group and the control group are normally distributed. This is in accordance with the criteria if sig $>0.05$, then the data is normally distributed (Siregar, 2014).

And for homogeneity test results data from the Physics Education student pre-test listed in table 3.

Table 3: Homogeneity test results of Physics Education study program

\begin{tabular}{llll}
\hline $\begin{array}{l}\text { Levene } \\
\text { Statistics }\end{array}$ & df1 & df2 & Sig. \\
\hline 0.024 & 1 & 106 & 0.878 \\
\hline
\end{tabular}

Homogeneity test results at a significance level of $5 \%$ obtained a significance value of 0.878 . Based on the significance of the results it can be concluded that the mastery of SPS data from the experiment group and the control group students have the same variant. This is in accordance with the criteria if the value is sig. $>0.05$, and then the two data tested are homogeneous.

As for the data on normality test results from Biology Education student, pre-tests can be seen in table 4.

Table 4: Results of normality tests in Biology Education study programs

\begin{tabular}{lccc}
\hline & \multicolumn{3}{c}{ Kolmogorov-Smirnov } \\
\cline { 2 - 4 } & Statistik & Df & Sig. \\
\hline Exsperiment & 0.101 & 41 & $0.200^{*}$ \\
\hline Control & 0.117 & 41 & 0.178 \\
\hline
\end{tabular}


The normality test was carried out at a significance level of 5\%, obtained the significance value of the experiment group 0.200 and the significance value of the control group. Based on the significant value it can be concluded that the mastery of SPS data in the experiment group and the control group are normally distributed. This is in accordance with the criteria if sig $>0.05$, then the data is normally distributed (Siregar, 2014). For homogeneity test results from Biology Education students, the pre-test can be seen in table 5.

Table 5: Homogeneity test results from Biology Education study programs

\begin{tabular}{llll}
\hline $\begin{array}{l}\text { Levene } \\
\text { Statistics }\end{array}$ & df1 & df2 & Sig. \\
\hline 4.416 & 1 & 85 & 0.079 \\
\hline
\end{tabular}

Homogeneity test results at a significance level of $5 \%$ obtained a significance value of 0.079 . Based on the significance of the results it can be concluded that the mastery of SPS data from the experiment group and the control group students have the same variant. This is in accordance with the criteria if the value is sig. $>0.05$, and then the data tested are homogeneous.

Then after normality and homogeneity tests were carried out, an analysis of the results of the SPS students' mastery of physics and Biology Education students both the experiment and control groups. The results of observations from the experiment and control groups in the Physics Education study program were analyzed using the independent sample ttest to get the results as in table 6 .

Table 6: t-test results for independent samples of Physics Education study programs

\begin{tabular}{lllll}
\hline Mastery of the SPS & \multicolumn{1}{l}{ T } & df & Sig. (tailed 2) \\
\hline $\begin{array}{l}\text { The same variance is } \\
\text { assumed }\end{array}$ & 12.534 & 106 & 0.000 \\
\hline $\begin{array}{l}\text { The same variance is not } \\
\text { assumed }\end{array}$ & 12.534 & 105.397 & 0.000 \\
\hline
\end{tabular}

Based on the results of the independent sample t-test at a significance level of 5\%, the significance value (the same variant is assumed) is obtained 0,000. Because of the significance value $>0.05$, it was concluded that there were differences in SPS mastery in the experiment group and the control group. The results of observations from the experiment and control groups in the Biology Education study program were analyzed using the independent sample ttest to get the results as in table 7.

Table 7: Analysis results for independent samples of t-test in Biology Education study programs

Mastery of the SPS
$\begin{aligned} & \text { The same variance is } \\ & \text { assumed }\end{aligned}$

Based on the results of the independent sample t-test at a significance level of $5 \%$, the significance value (the same variant is assumed) is obtained 0,000. Because of the significance value $>0.05$, it was concluded that there were differences in SPS mastery in the experiment group and the control group. The results of the parametric statistical analysis of the physical education program can be seen in Table 8.

Table 8: Results of statistical parameter analysis of the Physics Education study program

\begin{tabular}{llllllllll}
\hline \multirow{2}{*}{ Group } & Mean & Mode & $\begin{array}{l}\text { Std. } \\
\text { Deviation }\end{array}$ & Range & Min & Max & Quartile & \\
\cline { 7 - 11 } & & & & & & & Q1 & Q3 & Q \\
\hline Experiment & 3.01 & 3 & 0.292443 & 1.4 & 2.16 & 3.56 & 2.87 & 3.01 & 3.22 \\
\hline Control & 2.33 & 2.42 & 0.271102 & 1.05 & 1.79 & 2.84 & 2.13 & 2.35 & 2.55 \\
\hline
\end{tabular}

In general, the value of the statistical parameters in the experiment group was higher than in the control group. The mean value of the experiment group (3.01) is greater than the mean value in the control group (2.33). This is supported by the quartile value of the experiment group greater than the quartile value in the control group. Based on these parameters, it can be concluded that the mastery of the experiment group he experiments group SPS is better than the control group SPS. As for the results of the parametric statistical analysis of Biology Education, the study program can be seen in table 9. 
Table 9: Results of analysis of statistical parameters from the Biology Education study program

\begin{tabular}{lllllllllll}
\hline \multirow{2}{*}{ Group } & \multirow{2}{*}{ Mean } & \multirow{2}{*}{ Mode $\begin{array}{l}\text { Std. } \\
\text { Deviation }\end{array}$} & Range & Min & Max & & & & Quartile & \\
\hline Experiment & 3.28 & 3.4 & 0.243103 & 1.04 & 2.69 & 3.73 & 3.13 & 3.34 & 3.43 \\
\hline Control & 2.57 & 2.52 & 0.178153 & 0.86 & 2.11 & 2.97 & 2.5 & 2.54 & 2.69 \\
\hline
\end{tabular}

In general, the value of the statistical parameters in the experiment group was higher than in the control group. The mean value of the experiment group (3.28) is greater than the mean value in the control group (2.57). This is supported by the quartile value of the experiment group greater than the quartile value in the control group. Based on these parameters, it can be concluded that the mastery of the experiment group SPS is better than the control group SPS. From the results of observations of SPS, students obtained the SPS indicator mastery distribution in the experiment group of Physics Education study programs listed in table 10.

Table 10: Distribution of SPS indicator mastery in the experiment group of Physics Education study programs

\begin{tabular}{lllll}
\hline Indicator & Poor & Low & High & Excellent \\
\hline Meansuring & 1 & 3 & 20 & 30 \\
\hline Classifying & 0 & 3 & 18 & 33 \\
\hline Inferring & 2 & 17 & 33 & 2 \\
\hline Obtaining and processing data & 2 & 7 & 32 & 13 \\
\hline Describing relationship between variables & 1 & 24 & 22 & 7 \\
\hline Creating graph & 2 & 24 & 25 & 3 \\
\hline Creating data tables & 0 & 3 & 14 & 37 \\
\hline Formulating hypothesis & 0 & 27 & 20 & 7 \\
\hline Identifying variables & 9 & 38 & 6 & 1 \\
\hline
\end{tabular}

Based on the results of the mastery of KPS students in the Physical Education Study Program show that in the experiment group students have a good SPS. The indicators concluded that the experiment group was more dominant in Physics Education. The distribution of students' SPS mastery in the control group in the Physics Education study program is listed in table 11 .

Table 11: Distribution of masters of Indicators SPS control group Physics Education study program

\begin{tabular}{lllll}
\hline Indicator & Poor & Low & High & Excellent \\
\hline Meansuring & 0 & 19 & 32 & 3 \\
\hline Classifying & 2 & 6 & 29 & 17 \\
\hline Inferring & 21 & 28 & 4 & 1 \\
\hline Obtaining and processing data & 3 & 32 & 16 & 3 \\
\hline Describing relationship between variables & 24 & 27 & 2 & 1 \\
\hline Creating graph & 20 & 17 & 15 & 2 \\
\hline Creating data tables & 2 & 8 & 31 & 13 \\
\hline Formulating hypothesis & 5 & 25 & 22 & 2 \\
\hline Identifying variables & 24 & 23 & 4 & 3 \\
\hline
\end{tabular}

Table 11 Show that the average mastery of the indicators of SPS in the control group is categorized as not good. The indicators that are most mastered by students are classification indicators. An indicator that is not controlled by students is an indicator describing the relationship between variables. From the results of observations by SPS students, the SPS indicator mastery distribution in the experiment group of Biology Education study programs is listed in table 12.

Table 12 Shows that the average experiment group student from a Biology Education study program has mastered SPS very well. The dominant classifying indicators are most mastered by experiment group students in Biology Education study programs. While the hypothesis making indicator is a dominant indicator that cannot be controlled by experiment group students in Biology Education study programs. The distribution of SPS indicator mastery in the Biology Education study program in the control group is shown in table 13 . 
Table 12: Distribution of masters of SPS indicators in the experiment group Biology Education study program

\begin{tabular}{lllll}
\hline Indicator & Poor & Low & High & Excellent \\
\hline Meansuring & 0 & 5 & 22 & 20 \\
\hline Classifying & 0 & 2 & 10 & 35 \\
\hline Inferring & 1 & 7 & 15 & 24 \\
\hline Obtaining and processing data & 0 & 3 & 11 & 33 \\
\hline Defining variables & 0 & 6 & 9 & 32 \\
\hline Describing relationship between variables & 3 & 5 & 15 & 24 \\
\hline Creating graph & 4 & 7 & 15 & 21 \\
\hline Formulating hypothesis & 2 & 3 & 31 & 11 \\
\hline Identifying variables & 3 & 6 & 24 & 14 \\
\hline
\end{tabular}

Table 13: Distribution of mastery of SPS control group Biology Education study programs

\begin{tabular}{lllll}
\hline Indicator & Poor & Low & High & Excellent \\
\hline Meansuring & 1 & 16 & 24 & 6 \\
\hline Classifying & 3 & 9 & 34 & 1 \\
\hline Inferring & 2 & 24 & 20 & 1 \\
\hline Obtaining and processing data & 0 & 15 & 32 & 0 \\
\hline Describing relationship between variables & 3 & 30 & 13 & 1 \\
\hline Creating graph & 2 & 26 & 19 & 0 \\
\hline Formulating hypothesis & 3 & 14 & 29 & 1 \\
\hline Identifying variables & 8 & 30 & 8 & 1 \\
\hline
\end{tabular}

Table 13 shows that the average mastery of SPS indicators in the control group is well categorized. The indicator most mastered by students is the Obtaining and processing data indicator. Whereas the least indicator is mastered by students is an indicator to obtain and process data.

\section{DISCUSSION}

The results of hypothesis testing using independent sample t-test at a significance level of $5 \%$ stated that there were differences in the mastery of science SPS between the experiment group students and students in the control group in the Physics Education and Biology Education study programs. Based on statistical parameters it is known that the mastery of the SPS experiment group is better than the mastery in the control group in each study program. This shows that to support practicum activities that increase student SPS, it requires a pandan practicum that demands aspects of student KPS (Darmaji, Kurniawan, Astalini, Lumbantoruan, \&Samosir, 2019). The average mastery of SPS students in the experiment group was categorized as good. While the average student in the control group was categorized as not good.

The results showed that the use of a basic physics practicum guide I about SPS-based equilibrium using inquiry models can help experiment group students master SPS. This finding is in accordance with the results of research conducted by Zulaiha (2014), (Darmaji, Kurniawan, \& Lestari, 2018), the application of SPS-based practicum guidance can improve students' SPS abilities. In addition, the findings of this study are also consistent with the research of Adnyana \& Citrawathi (2017) that the application of QBIM effectively increases students' knowledge and SPS.

This practicum guidebook has a problem-recognition presentation on work steps created in the form of questions that greatly helps students to conduct experiments. The questions in this guide lead students to look for answers by conducting experiments. These questions stimulate students to make hypotheses, design experiments, and experiments to prove their hypotheses. So students are able to plan experiments, design experiments to prove their hypotheses.

Mastery of SPS is high in the experiment group because the practicum guidelines have parts in developing all SPS indicators. SPS indicators developed through the practicum guide include: observation skills, experiment planning, experiment analysis, conducting experiments, defining variables, measuring, creating data tables, obtaining and processing data, inferring, predictions, classifications, describing relationships between variables, communication, making graphs, make hypotheses and identify variables.

In the practicum, guides make it easy for students to recognize problems from the steps of work to do the practicum. A guide that directs students to find answers through experiments, because it is able to stimulate students to make 
hypotheses, design experiments, and conduct experiments to prove hypotheses (Adnyana \& Citrawathi, 2017). Learning done by students before doing an experiment first makes an experiment design.

\section{SPS Mastery in Physics Education students}

In the experiment group students have good SPS mastery. Students have the best skills in making table indicators because it appears that at the time of the practicum, students are able to present the results of experiments on a table with the right label and are able to present the results of repeated measurements using column numbers. After presenting the experiment data through a table, students are also able to present the results of experimental data using graphs on millimeter paper. So that the experimental data presented is more communicative. Good student skills in making tables because students have mastered basic SPS well. Mastering basic SPS is a prerequisite for increasing integrated SPS (Zeidan \& Jayosi, 2015). Students' ability in making tables is influenced by their ability to master classifying skills.

The SPS indicator that is least mastered by students in the experiment group is the skill of identifying variables. Students are still confused in determining the independent variable, the dependent variable, and the control variable. This is because practical guidelines have not clearly directed students to identify each experiment variable. When practicing, participants are still at the learning and training stages, so there is a need for clear practical guidelines_Asy'syakurni, Widiyatmoko, \&Parmin, 2015). The guide only contains definitions of what are independent variables, dependent variables, and control variables without examples. Based on the interim report, most students can only identify the dependent variable.

In the control group, it appears that students have good SPS mastery. SPS mastery is best at communicating skills indicators. Students' ability to classify appears from the ability of students to classify objects when practicum based on similarities, differences or relationships between 2 objects (Ozgelen, 2012). Students have mastery of SPS in classifying skills because the conventional guidelines contain an experiment data table. Students in the control group are very unskilled in identifying independent variables, dependent variables and control variables. This is because the practical manual used by students in the experiment group does not explain the three variables. so it makes sense if students in the experiment group cannot master indicators that correctly identify variables.

The results of the analysis on each science process skills indicator label indicate a significant difference in the value of each indicator label. The science process skills of students are measured through performance by applying scientific methods. The independence of students in the experiment class in determining the steps of taking data through observation is also better than the control class. Among the indicators of science process skills, the highest score achieved by a group of experiment class students is an indicator of obtaining and processing data. In the control class students of Physics Education have high skills in measuring indicators because it involves students from the beginning to the end of the learning process, from arranging problems to be discovered, planning the discovery process, to finding the product.

\section{Mastery of SPS in Biology Education study programs}

In the experiment group, students have good mastery. Students have the best mastery of indicators to process and process data. Student skills appear from the ability of students to present all the experiment data in a table and be able to process through the analysis of data that is completed without seeing from a group of friends but able to do it by themselves. Good mastery is in the indicator of identifying variables because the practical guide does not provide an explanation that can be understood by students about what variables are, and how to identify the independent variables, dependent variables, and constant variables. SPS mastery in the control group is not good, because students have not been able to conduct experiments skilfully; most of them still ask their peers during the experiment.

In the control class Biology Education students have high skills in obtain and process data, this is influenced by the ability of students who are advanced in the skills to make classifications because classification process skills are process skills that are important in obtaining and processing data used to obtain concepts. The discovery process skills themselves will be more useful for students so that the knowledge possessed is difficult for students to forget. Cognitive development resulting from the dialectical process whereby a student who learns through the experience of problemsolving will be used to share with others.so students must have science process skills to gain meaningful and useful knowledge.

So from the results of the study, it is known that there are differences in SPS mastery of students who are in the experiment group who use guidelines that demand mastery of SPS and students who are in the control group who still use conventional guidelines.

\section{CONCLUSION}

The results of this study indicate that there are differences in SPS mastery between students who use SPS-based practicum guides and students who use conventional practicum manuals in Physics and Biology Education study programs. Based on the results of hypothesis testing using the independent sample t-test at a significance level of 5\%, a significance value of 0,000 was obtained in the physics and Biology Education study program. Where based on 
statistical parameters used it can be concluded that the SPS mastery of the experiment group is better than the SPS mastery in the control group.

\section{LIMITATION AND STUDY FORWARD}

Some considerations found using this guide include: there is no need for drawings for the steps of the experiment so students choose perfection for the experiment experiments, and still discuss the variables that must be done by students.

The results in this study can be used as input for Physics Education, Faculty of Teaching and Education, Universitas Jambi to consider the use of process skills-based practical guides,

\section{ACKNOWLEDGEMENT}

This research would not have been possible without the help and support of several people. Researchers would like to thank students of the Physics Education and Biology Education study programs. The researcher also thanks to the advisors and the research team who assisted in conducting this research.

\section{AUTHORS CONTRIBUTION}

Maison is a professor in the field of physics education in the field of physics (science) curriculum, misconceptions and characters. As the lead researcher with the task carried out is to coordinate the entire research performance from the preparation of research instruments to the results of research data analysis. This research is useful to map students' abilities in terms of character, an attitude so that it can be given a curriculum evaluation and new curriculum innovations in terms of character and attitude enhancement.

Retni Sulistiyoning Budiarti is an associate professor. The focus of the field of research is the character, entrepreneurship, and microbiological content for science education. In this study, he was a secretary who accommodated and evaluated the results of research at the junior high school level in learning science.

Sofia Christine Samosir is a postgraduate student at Universitas Jambiy. In this study, he was a member whose job was to collect and input research data in the Physics Education and Biology Education.

Neng Ria Nasih is a postgraduate student at Universitas Jambi. In this study, he was a member in charge of processing data and analyzing research data, research data in physics education and biology education.

\section{REFERENCES}

1. Adnyana, P. B., \& Citrawathi, D. M. (2017). The Effectiveness of Question-Based Inquiry Module in Learning Biological Knowledge and Science Process Skills.International Journal Of Environmental \& Science Education, 12(8), 1871-1878.

2. Agustina, P., \& Saputra, A. (2016). Analisis Keterampilan Proses Sains (KPS) Dasar Calon Mahasiswa Guru Biologi Pada Matakuliah Anatomi Tumbuhan (StudiKasusMahasiswa Prodi P. Biologi FKIP UMS TahunAjaran 2015/2016).Seminar NasionalPendidiknSains,71-78.

3. Arifin, Z., Silaban, R., \&Tarigan, S. (2017). AnalisisBukuPanduanPraktikum Kimia Kelas 12 Semester GanjilBerdasarkanKurikulum 2013.IOSR Journal of Research \& Method in Education ,7(6), 61-65.

4. Asrial, et al, (2019).Identification: The Effect Of Mathematical Competence On Pedagogic Competency Of Prospective Teacher. Humanities \& Social Sciences Reviews, 7(4), 85-92.

5. Astalini, Darmaji, Kurniawan, W., Anwar, K., \&Kurniawan, D. A. (2019). Effectiveness of Using E-Module and E-Assessment.International Journal Interactive Mobile Technologies (IJIM), 9(13), 21-39. https://doi.org/10.3991/ijim.v13i09.11016

6. Astalini, Kurniawan, D. A., Perdana, R., \& Kurniasari, D. (2018). Identification of Student Attitudes toward Physics Learning at Batanghari District High School. The Educational Review, USA, 2(9), 475-484. https://doi.org/10.26855/er.2018.09.003

7. Astalini, Kurniawan, D. A., Darmaji, Putri, A. D., \&Nawaningsih, R. (2019).Identifiy student's attitude towards the subject of natural science.Journal of Education and Learning (EduLearn), 13(3), 386-394.

8. Astalini, Kurniawan, D. A., Darmaji, Sholihah, L. R., \& Perdana, R. (2019). Characteristics of students' attitude to physics in muaro jambi high school. Humanities and Social Sciences Reviews, 7(2), 91-99. https://doi.org/10.18510/hssr.2019.7210

9. Astalini, Kurniawan, D. A., Sulistiyo, U., Perdana, R., \& Susbiyanto. (2019). E-assessment motivation in physics subjects for senior high school. International Journal of Online and Biomedical Engineering,15(11),415. https://doi.org/10.3991/ijoe.v15i11.10843

10. Astalini, Kurniawan, D. A., Melsayanti, R., \&Destianti, A. (2018).Sikap Terhadap Mata Pelajaran IPA Di SMP Se-Kabupaten Muaro Jambi.LenteraPendidikanJurnallmuTarbiyah Dan Keguruan,21(2),214-227. https://doi.org/10.24252/lp.2018v21n2i7

11. Asy'syakurni, N. A., Widiyatmoko, A., \&Parmin.(2015). EfektivitasPenggunaanPetunjukPraktikum IPA BerbasisInkuiriPadaTemaKalor Dan PerpindahannyaTerhadapKeterampilan Proses SainsPesertaDidik.Unnes Science Education Journal, 4 (3), 952-959. 
12. Cohen, L., Manion, L., \& Morrison, K. (2007). Research Methods in Education. Routlege. https://doi.org/10.4324/9780203029053

13. Darmaji, Astalini, Rahayu, A., \&Maison, (2018).Development Physics Practical Guided Based On Science Process Skill Using Problem Solving, EDUSAINS, 10(2),83-96. https://doi.org/10.15408/es.v10i1.7214

14. Darmaji, et al, (2019).Students' perceptions of electronic's module in physics practicum. Journal of Education and Learning (EduLearn), 13(2), 288-294.

15. Darmaji, et al, (2019).Practicum Guide: Basic Physics Based Of Science Process Skills. Humanities \& Social Sciences Reviews, 7(4), 151-160. https://doi.org/10.18510/hssr.2019.7271

16. Darmaji, Kurniawan, D. A., Astalini, Lumbantoruan, A., \&Samosir, S. C. (2019).Mobile Learning in Higher Education for The Industrial Revolution 4.0: Perception and Response of Physics Practicum. International Journal Interactive Mobile Technologies (IJIM), 9(13), 4-20. https://doi.org/10.3991/ijim.v13i09.10948

17. Darmaji, Kurniwan, D. A., \& Irdianti. (2019). Physics Education Students' Science Process Skills in Universitas Jambi. International Journal of Evaluation and Research in Education (IJERE), 8(2), 293-298.

18. Darmaji, Kurniawan, D. A., \& Lestari, A. (2018).DeskripsiKeterampilan Proses SainsMahasiswaPendidikanFisikapadaPraktikumSuhudanKalor.JurnalRisetdanKajianPendidikanFisika, 5 (2), 68-72. https://doi.org/10.12928/jrkpf.v5i2.10735

19. Darmaji, Kurniawan, D. A., Parasdila,H., \& Irdianti. 2018. "Description of Science Process Skills' Physics Education Students at Jambi University in Temperature and Heat Materials". Educational Review, USA,Vol. 2,No. 9, pp. 485-498. https://doi.org/10.26855/er.2018.09.005

20. Darmaji, D., Kurniawan, D. A., \& Suryani, A. 2019. "Effectiveness of Basic Physics II Practicum Guidelines Based On Science Process Skills". (JIPF) Jurnal Ilmu Pendidikan Fisika, Vol.4, No. 1. https://doi.org/10.26737/jipf.v4i1.693

21. Ernawati, M. D. W. Damris, M., Asrial, \&Muhaimin. (2019). Development of Creative Thinking Skill Instruments for Chemistry Student Teachers in Indonesia.International Journal of Online and Biomedical Engineering (iJOE), 15(14),21-30. https://doi.org/10.3991/ijoe.v15i14.11354

22. Gall, M. D., Gall, J. P., \& Borg, W. R. (2003). Educational Research An Introduction 7th Edition. Pearson Education Inc.

23. Hirca, N. (2013). Pengaruh Tanganpada Eksperimen Fisikapada Keterampilan Proses Ilmiah Menurut Pengalaman Calon Guru. Jurnal Eropa Pendidikan Fisika , 4 (1), 6-15.

24. Karadan, M., \& Hameed, D. A .(2016). Curricular Representation of Science Process Skills in Chemistry. IOSR Journal of Humanities and Social Science, 21(8), 1-5. https://doi.org/10.9790/0837-2108120105

25. Kusuma, M. D., Rosidin, U., Abdurrahman, A., \& Suyatna, A. The Development of Higher Order Thinking Skill (Hots) Instrument Assessment In Physics Study.(2017). IOSR Journal of Research \& Method in Education (IOSRJRME),7(1), 26-32. https://doi.org/10.9790/7388-0701052632

26. Misbah, Wati, M., Rif'at, MF, \&Dyah, MP (2018).PengembanganPenuntunPraktikumFisikaDasar I Berbasis 5M Untuk Melatih Keterampilan Proses Sainsdan Karakter Wasaka. JurnalFisikaFLUX ,15(1),26-30. https://doi.org/10.20527/flux.v15i1.4480

27. Ozgelen, S. (2012).Students' Science Process Skills within a Cognitive Domain Framework.Eurasia Journal of Mathematics, Science \& Technology Education, 283-292. https://doi.org/10.12973/eurasia.2012.846a

28. Rezba, R. J., Sprague, C. R., McDonnough, J. T., \&Matkins, J. J. 2007. Learning and Assessing Science Process Skills.Kendaal/Hunt Publishing Company.

29. Siregar, S. (2014). Statistik Parametrik untuk Penelitian Kuantitatif Dilengkapi dengan Perhitungan Manual dan Aplikasi SPSS Versi 17. Jakarta: Bumi Aksara.

30. Syarial, Asrial, Kurniawan, D. A., \&Subandiyo, M. (2019). Pedagogic Competence And Insonesian Language Competence Pre-Service Teacher Of Elementary Program. International Journal Of Scientific \& Technology Research (IJSTR), 8(10), 851-856

31. Asrial, Syahrial, Kurniawan, D. A., Subandiyo, M., and Amalina.Exploring Obstacles in Language Learning Among Prospective Primary School Teacher.International Journal of Evaluation and Research in Education (IJERE), vol. 8 no. 2, pp. 249-254, 2019.

32. Syahrial, et al. (2019).The impact of etnocontructivism in social affairs on pedagogic competencies.International Journal of Evaluation and Research in Education (IJERE), vol. 8 no. 3, pp. 409416, 2019.

33. Wijayanto, E. (2018). Pengembangan Penuntun Praktikum Fisika Dasar 1 Materi Kesetimbangan Berbasis keterampilan Proses Sains Menggunakan Model Inkuiri. Jambi: Universitas jambi.

34. Zeidan, AH, \&Jayosi, MR (2015).SPS danSikapterhadapSains kalanganSiswaSekolahMenengahPalestina. World Journal of Education,13-24. 13-24

35. Zulaiha, Hartono, \& Ibrahim, A. R. (2014).PengembanganBukuPenuntunPraktikum Kimia HidrokarbonBerbasisKeterampilan Proses Sains Di SMA. JurnalPendidikan Kimia,1 (1), 87-93 